\title{
MASERIA VESPERTILIONIS n.g., n.sp. (DOR YLAIMINA : MUSPICEIDAE), a Nematode from Nearctic Bats (Vespertilionidae)
}

\author{
R. L. RAUSCH and V. R. RAUSCH*
}

\begin{abstract}
SUMMARY. Maseria vespertilionis n. g., n. sp. (Dorylaimina : Muspiceidae) is described from nearctic bats (Vespertilionidae). In addition to the type host, Eptesicus fuscus (P. de Beauvois), in Oregon, $M$. vespertilionis was recorded from Myotis volans (Allen) in Oregon, and from $M$. lucifugus (Le Conte) in Oregon and Alaska. The nematode was found only in subcutaneous tissues near the plantar surface of the rear feet of the host. The genus Maseria is distinguished from other genera in Muspiceidae by various morphological characteristics, among which the presence of a Demanian system is important. The lesions produced in the feet of the host are described, and other biological characteristics of the nematode are discussed.
\end{abstract}

\section{Description de Maseria vespertilionis n.g., n.sp., Nématode (Dorylaimina : Muspiceidae) parasite de chauves-souris (Vespertilionidae néaretiques.)}

RÉSUMÉ. Ce Nématode a été trouvé dans le tissu sous-cutané des pieds d'Eptesicus fuscus (P. de Beauvois) et de Myotis volans (Allen) d'Oregon et de Myotis lucifugus (Le Conte) d'Oregon et d'Alaska. Maseria n. g. diffère des autres Muspicéides par divers caractères, et en particulier par la présence d'un système de De Man. Les lésions dans les pieds de l'hôte son décrites, et la biologie du Nématode est brièvement discutée.

Nematodes of five species representing three genera of the family Muspiceidae Brumpt, 1930 are known to occur in subcutaneous tissues of bats, usually in the wing- or interfemoral membranes (Bain and Chabaud, 1979). Infected bats have been reported from western Eurasia, Africa, northern South America, and Australia. A single occurrence of such a nematode in the wing-membrane of a nearctic bat was noted by us, based on findings in tissue-sections. Still another species, considered below, has been found in subcutaneous tissues of the rear feet of bats in western North America.

* Division of Animal Medicine SB-42, School of Medicine, University of Washington, Seattle, Washington 98195, U.S.A.

Accepté le 20 septembre r982. 
This nematode was first observed by Mr. C. Maser, in lesions on the plantar surfaces of the digits of a big brown bat, Eptesicus fuscus (P. de Beauvois), captured on 27 August 1971 near Otis, Lincoln County, in the coastal forest of western Oregon. During the following nine years, Mr. Maser provided additional material and data from a large series of bats from various localities in Oregon. In July 1974, we obtained the same nematode from little brown bats, Myotis lucifugus (Le Conte), in central Alaska. Additional bats from Alaska have been provided by Mr. D. G. Ritter.

The purpose of the present paper is to describe this nematode, for which the designation Maseria vespertilionis n.g., n.sp., is proposed, and to consider some of its biological characteristics.

\section{Materials and Methods}

In Oregon, bats were collected by shooting and with use of nets. Some also were obtained from maternity colonies. In Alaska, bats were not selectively collected; most of those examined had been received in the laboratory for diagnostic tests for the virus of rabies. Feet exhibiting the characteristic lesions caused by the nematodes usually were removed and fixed in a $10 \%$ solution of formalin, or the bats were preserved entire. The nematodes were dissected from the host-tissues with aid of a stereoscopic microscope, after which they were cleared in glycerin by standard methods. Selected specimens were stained in weak solutions of rose Bengal or Lichtgrün in glycerin. Transverse sections and cephalic ends were mounted in glycerin jelly. For study of the nematodes in situ, the feet were embedded in paraffin, after which sections were cut serially and stained in hematoxylin-eosin, Gomori's trichrome, and by the periodic acid-Schiff method.

\section{Results}

The nematode was found only in the digits of the rear feet of bats (fig. 1). Thirty-one $(4.5 \%$ ) of 684 animals examined in Oregon, and 6 of 28 in Alaska, were infected. The nematode was recorded from only three species of the 13 represented in a series of 712 animals : Myotis lucifugus, M. volans (Allen), and Eptesicus fuscus. Data concerning host-occurrence and prevalence for bats collected in Oregon are summarized in Table $I$.

\section{Maseria n.g.}

Diagnosis : Muspiceidae. Small, robust nematodes; translucent, with transversely striated cuticle. Amphids cyathiform. Oral opening slightly ventral. Oesophagus long and narrow, terminating just posterior to lateroventral stichocytes, and communicating with trophosome by thin duct associated with Demanian system. Single subventral oesophageal gland situated just posterior to nerve ring. Two lateroventral 


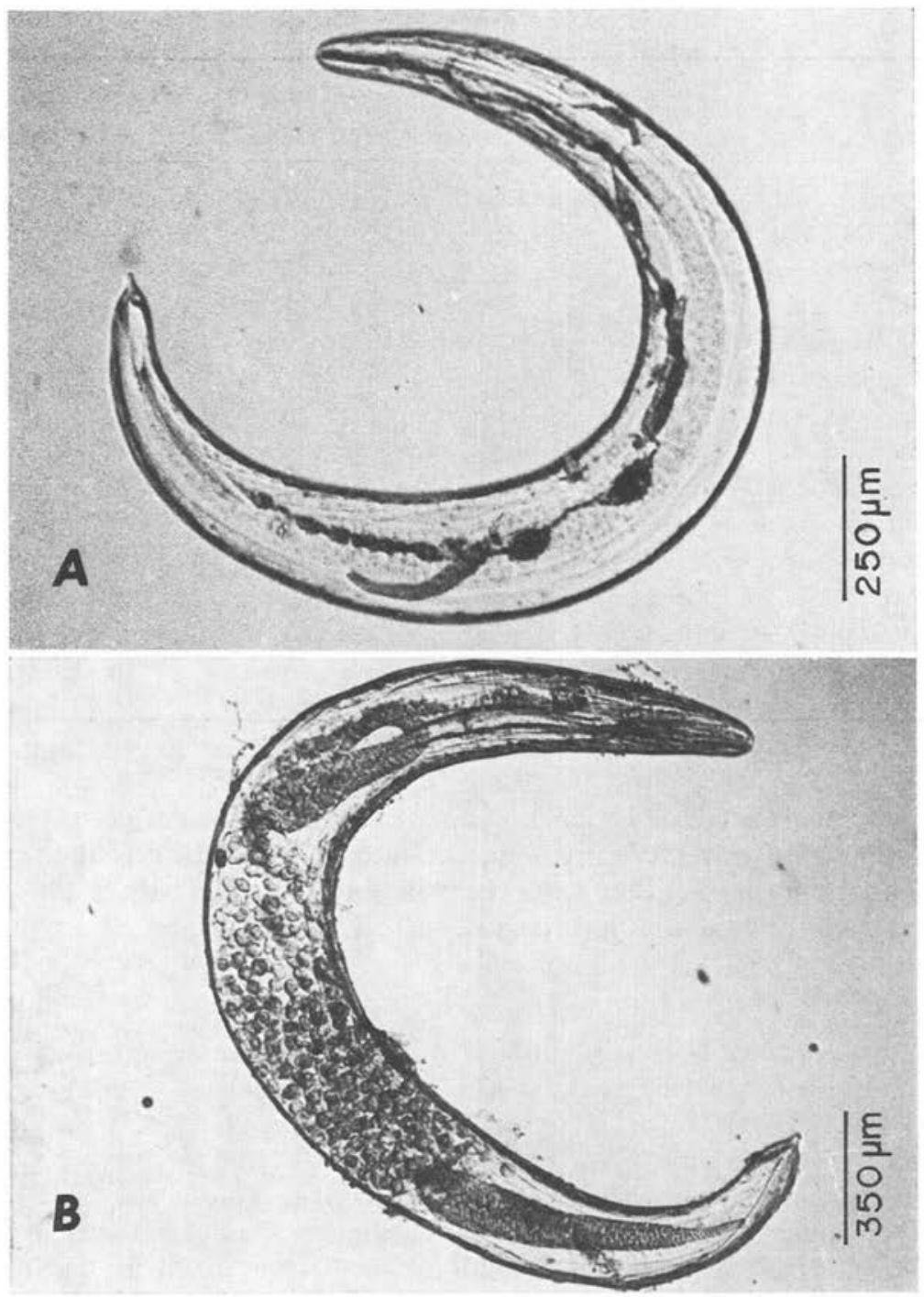

FIG. I. - Maseria vespertilionis n. g., n. sp., formalin-preserved.

A) Immature specimen. B) Pregravid specimen.

stichocytes present. Posterior dorsal osmoexcretory cell at level of posterior end of oesophagus. Alimentary canal nonfunctional in adult nematodes. Trophosome present. Anus lacking. Proterandric hermaphroditic. Uterus didelphic, with ovaries usually reflexed; oviduct present. Vagina well developed; vulva not opening to 
TABLE I. - Prevalence of Maseria vespertilionis in bats in Oregon.

\begin{tabular}{lrc}
\hline \multicolumn{1}{c}{ Species } & $\begin{array}{c}\text { Number } \\
\text { examined }\end{array}$ & $\begin{array}{c}\text { Number } \\
\text { infected }\end{array}$ \\
\hline Myotis californicus (Audubon and Bachman) & 77 & - \\
M. leibi (Aud. and Bach.) & 6 & - \\
M. yumanensis (Allen) & 35 & - \\
M. lucifugus (Le Conte) & 152 & $12 \%)$ \\
M. volans (Allen) & 99 & 1 \\
M. thysanodes Miller & 1 & - \\
M. evotis (Allen) & 81 & - \\
Lasionycteris noctivagans (Le Conte) & 65 & - \\
Pipistrellus hesperus (Allen) & 32 & - \\
Eptesicus fuscus (P. de Beauvois) & 82 & - \\
Lasiurus cinereus (P. de Beauvois) & 8 & - \\
Plecotus townsendi Cooper & 25 & 31 (4.5\%) \\
Antrozous pallidus (Le Conte) & 21 & \\
\multicolumn{1}{c}{ Totals : 13 species } & 684 & \\
\hline
\end{tabular}

exterior. Phasmids small and simple. Complex Demanian system present, situated dextral or sinistral to reproductive organs. Mature larva with cephalic armature. Known only from subcutaneous tissues of rear feet of nearctic bats.

Type species: Maseria vespertilionis $\mathrm{n}$. sp.

\section{Generic comparisons}

Four genera have been recognized previously in the family Muspiceidae, viz., Muspicea Sambon, 1925; Riouxgolvania Bain and Chabaud, 1968; Lukonema Chabaud and Bain, 1974; and Pennisia Bain and Chabaud, 1979. Maseria n. g. is immediately distinguishable from the aforementioned by the presence of a complex Demanian system. Such a system has been observed previously only in females of certain marine nematodes of the family Oncholaimidae (Baylis and Daubney, 1926) (Oncholaimina) (zur Strassen, 1894; Cobb, 1930 ; Rachor, 1969). By analogy with the oncholaimids, the presence or absence of a Demanian system would not necessarily have taxonomic significance at the generic level. In the present case, however, since the validity of this analogy is uncertain with respect to nematodes assigned to different suborders, we recognize Maseria as a distinct taxon at that rank. Other morphological characteristics as well distinguish Maseria from the other genera of the Muspiceidae.

Maseria differs from Muspicea in lacking the four ventral oesophageal glands, in having a well developed vagina, a well developed oviduct, and larva with cephalic 
armature. It is distinguished from Lukonema by the lack of the ventral oesophageal glands (fused in a linear row in Lukonema), and by the absence of specialized phasmids. From Pennisia, it differs in being proterandric hermaphroditic and in lacking highly specialized phasmids. Maseria differs from Riouxgolvania in having a long oesophagus, with two lateroventral stichocytes at the posterior end, and in the presence of an anterior single subventral oesophageal gland situated just posterior to the nerve ring and emptying through a well defined duct into the oesophagus slightly more anteriad. Maseria lacks a posterior dorsal gland, which is present in Riouxgolvania. In Maseria, the oesophagus extends posteriad with the stichosome and terminates at the level of the two lateroventral stichocytes, beyond which a junction is formed with a thin-walled duct connecting with the Demanian complex and trophosome ; this connection is often discernible in mature females. In Maseria, as well, the female reproductive system differs from that of Riouxgolvania in the presence of well developed oviducts that pass from the respective ovaries to the uterus through a distinctly constricted area. Associated with the walls of each oviduct is a large sinus that communicates with both the Demanian system and the trophosome. From the examination of numerous gravid specimens we found no evidence that the larvae escape from the uterus of the living female, and consequently there was no indication of the intracuticular migration such as occurs in Riouxgolvania. Dead females in lesions no longer contained larvae, but the means by which they were expelled was not determined. Some differences apparently exist in the proterandric stages of nematodes of the two genera, since the vulva opens externally in $M$. vespertilionis, and the uterine tubes that serve as seminal receptacles are much elongated. In $R$. beveridgei Bain and Chabaud, 1979, for which the proterandric female has been described, the uterine tubes are very short and the vulva apparently does not open externally. In the mature larva of $M$. vespertilionis, there is a patent anal opening, whereas the rectum was described as being atrophied in $R$. beveridgei. Of biological differences, the most obvious is the invariable localization of $M$. vespertilionis in the digits of the hind feet of bats, where the nematodes typically form aggregations in single lesions.

\section{Description of Maseria vespertilionis n. sp. (fig. 2, 3, 4)}

The following description is based on 20 pregravid and gravid females, one proterandric female, and larvae removed from gravid females.

Mature female. Body small and robust ; translucent when alive and after fixation. Length 2.3 to $4.3 \mathrm{~mm}$; maximum diameter at level of vulva, 282 to $449 \mu \mathrm{m}$. Cuticle transversely striated. Oral opening subterminal, slightly ventral; appearing at surface as minute slit about $2-4 \mu \mathrm{m}$ in greater diameter. Three pairs of circumoral papillae present, arranged in two rows. Caudal extremity with small projection, about $17 \mu \mathrm{m}$ in length, terminating in four equal processes $2 \mu \mathrm{m}$ in length. Oesophagus slender, about $20 \mu \mathrm{m}$ in diameter; lumen usually $4 \mu \mathrm{m}$ in diameter, sometimes 

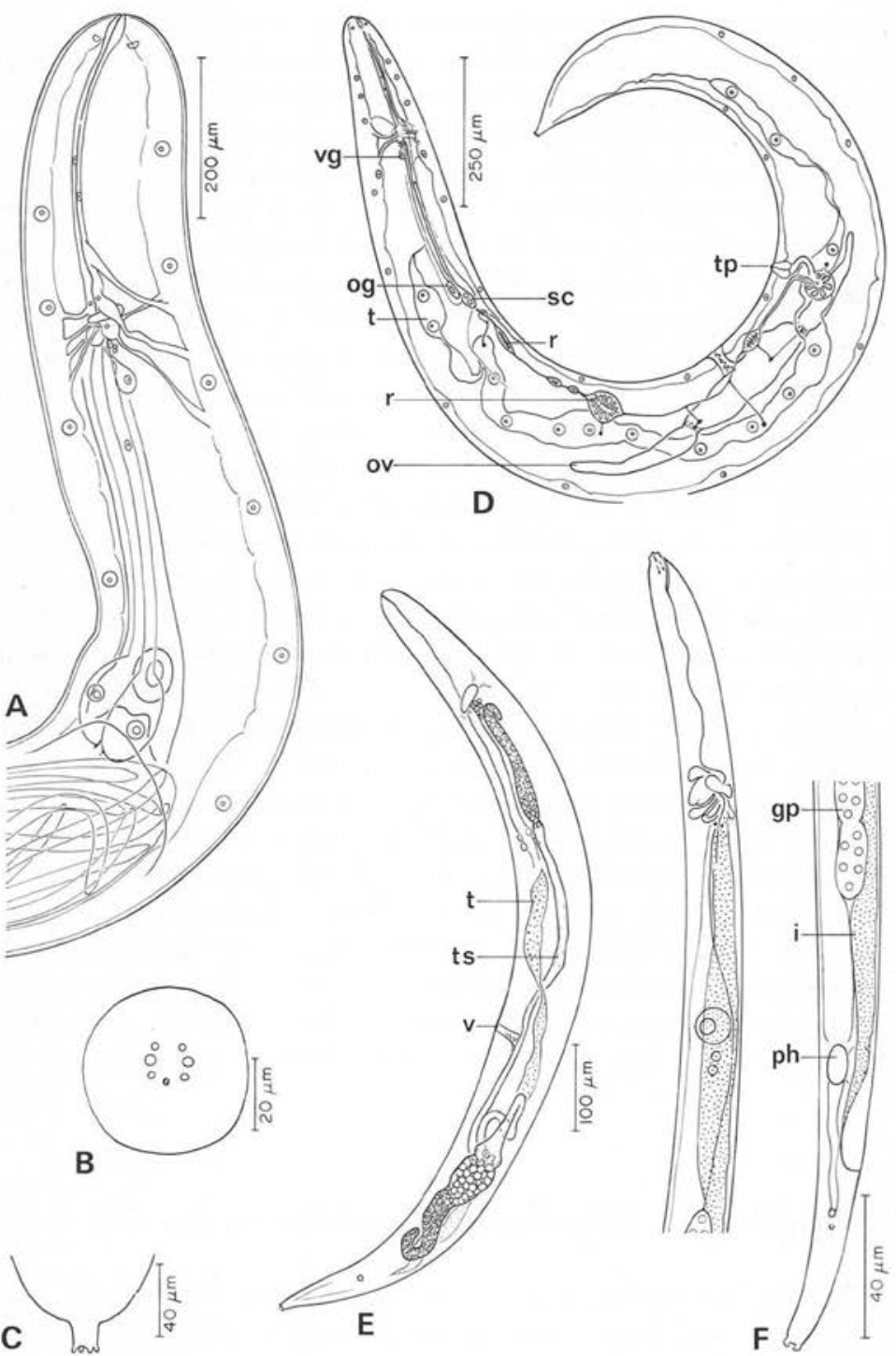

FIG. 2. - Maseria vespertilionis. A-F, morphological details. A) Cephalic end of gravid female (anterior end of uterus with larvae visible), ventrolateral view. B) Cephalic end, en face view. C) Caudal extremity. D) Immature specimen, showing relationships of trophosome, female genital organs, and Demanian system; lateral view. E) Proterandric nematode. F) Third-stage larva, from uterus of gravid female.

Symbols : $g p=$ primordium of genital organs $; \mathrm{i}=$ intestine $; \mathrm{og}=$ dorsal osmoexcretory gland $; \mathrm{ov}=$ ovary $; \mathrm{ph}=$ phasmid $; \mathrm{r}=$ rosette $; \mathrm{sc}=$ lateroventral stichocytes $; \mathrm{t}=$ trophosome; $\mathrm{ts}=$ tube (early-stage uterus) serving as seminal receptacle $; \mathrm{v}=$ vulva ; $\mathrm{vg}=$ subventral œsophageal gland. 


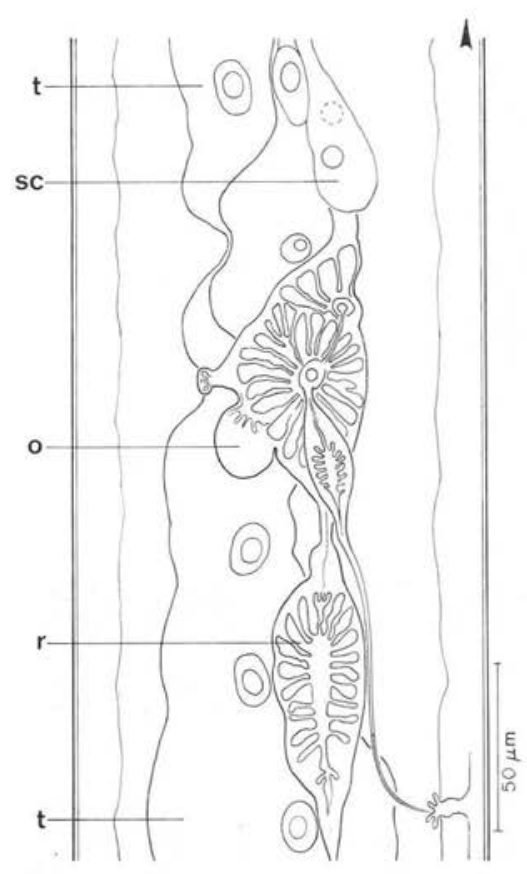

A

FIG. 3. - Maseria vespertilionis. A-C, details of Demanian system, lateral view (arrows point anteriad). A) Anteriormost portion of Demanian system, posterior to end of oesophagus. B) Middle portion, in vicinity of vagina. C) Posterior portion of system.

Symbols : $o=$ osmosium ; ov $=$ ova1y $;$ po $=$ pore in wall of vagina $; r=$ rosette ; $\mathrm{sc}=$ lateroventral stichocytes $; \mathrm{t}=$ trophosome $; \mathrm{tp}=$ terminal pore of Demanian system ; ut $=$ uterus.

distended just anterior to nerve ring. Oesophagus 498 to $822 \mu \mathrm{m}$ in length, extending posteriad to level of lateroventral stichocytes, there joining thin-walled duct connecting with Demanian system and trophosome. Extensions from dorsal, ventral, and lateral chords supporting oesophagus near middle of pseudocoel anteriorly ; ventral septum terminating a short distance anterior to nerve ring; dorsal septum not visible posterior to nerve ring. Lateral components forming transverse septum gradually shifting ventrad, persisting to level of lateroventral stichocytes ; there, bilateral components diverging at midline, each narrowing posterolaterad until no longer discernible in dorsal-ventral view (i.e., terminating about $1 \mathrm{~mm}$ from cephalic end). Nerve ring 276 to $412 \mu \mathrm{m}$ from cephalic end; associated with complex of ganglia and ligaments. Anterior subventral oesophageal gland with large nucleated cell, situated just posterior to nerve ring; duct arising from gland extends anteriad, joining oesophagus. Two large lateroventral stichocytes at posterior terminus of 


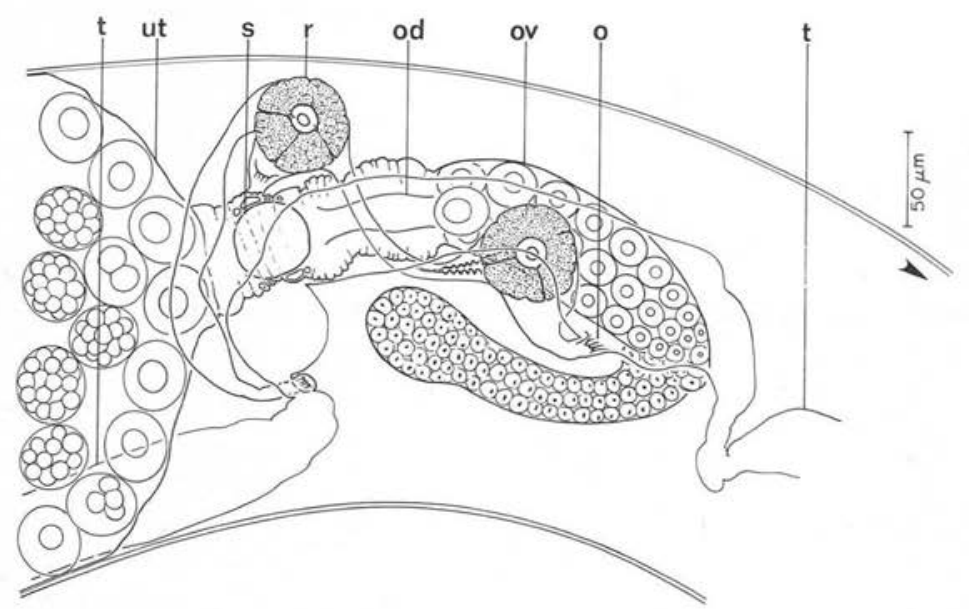

FIG. 4. - Maseria vespertilionis. Details of relationship of Demanian system with trophosome and female genital organs in pregravid nematode, lateral (dextral) view (arrow points anteriad).

Symbols : o $=$ osmosium ; od $=$ oviduct $; \mathrm{ov}=$ ovary $; \mathrm{r}=$ rosette $; \mathrm{s}=$ sinus (associated with sinistral wall of oviduct) connecting Demanian system and trophosome ; $t=t r o-$ phosome; ut $=$ uterus.

oesophagus; stichosome extending $380-450 \mu \mathrm{m}$ anteriad to level of nerve ring. Posterior dorsal osmoexcretory gland with large nucleated cell, extending anteriad from approximately same level as lateroventral stichocytes. Details of excretory system not established anteriorly. Anterior to nerve ring, two small nuclei associated with oesophagus at approximately half the distance to cephalic end; posterior to nerve ring, one small nucleus about mid-way to oesophageal terminus. Aggregation of small cells associated with complex of ganglia just posterior to nerve ring. Trophosome well developed, attached to lateral wall about $400 \mu \mathrm{m}$ from cephalic end, and extending posteriad to within about $250 \mu \mathrm{m}$ from caudal extremity ; anteriorly with connection to oesophagus. Anus lacking. Uterus didelphic, sac-like, with ovaries extending anteriad and posteriad from uterine extremities, and usually reflexed. Oviduct well developed, situated in contricted area between ovary and uterus. Large sinus, $c a 40 \mu \mathrm{m}$ in diameter, in sinistral wall of oviduct connected with trophosome and Demanian system. Vagina situated ventrally near middle of body, 1.3 to $1.9 \mathrm{~mm}$ from cephalic extremity, thick-walled, 57 to $146 \mu \mathrm{m}$ in length. Vulva not opening through cuticle. Larvae abundant, filling enlarged uterus and obscuring internal organs. Demanian system present (completely discernible only in immature females), situated ventrolaterally, dextral or sinistral to female reproductive organs ; five or six rosettes (uvettes) present, in more or less linear arrangement. Rosettes connected with uterus and trophosome by means of osmosia. Anteriormost rosette connected with trophosome; second rosette, farther posteriad, with connection to female genital tract at level of oviduct. Two connections of Demanian system with female 
reproductive organs observed; four with trophosome. From last (posteriormost) rosette, duct extending ventrad, opening through ventral wall, slightly laterally, by way of small papilla protruding from cuticular surface about $1 \mathrm{~mm}$ from caudal extremity in early gravid specimens, and about $475 \mu \mathrm{m}$ posterior to vulva. Papilla conical with concentric grooves. Terminal portion of duct at entry to papilla surrounded by collar of cells.

Proterandric female. Anatomy fundamentally like that of mature female. Body more slender, $1.04 \mathrm{~mm}$ long by $84 \mu \mathrm{m}$ in maximum diameter. Uterus relatively longer and narrower. Anterior ovary, with extremity reflexed, extending anteriad to about level of nerve ring. Posterior ovary, also reflexed, extending posteriad to about $160 \mu \mathrm{m}$ from caudal extremity. Lower part of posterior ovary and adjacent uterus dilated, filled with developing ova ; anterior ovary slender, lacking large ova. Uterus containing spermatozoa, much convoluted at earlier stage of development; functioning as seminal receptacle. Vulva with opening through cuticle to exterior. Trophosome well developed. Anus apparently lacking. Bilateral phasmidial pores present. No evidence of Demanian system observed.

Mature larva (from gravid females). Body slender, of comparatively uniform diameter ; 189 to $376 \mu \mathrm{m}$ in length by about 20 in maximum diameter. Cuticle transversely striated. Cephalic end with small, rounded projection; armed with four parallel ridges about $4 \mu \mathrm{m}$ long, on both lateral surfaces. Oral opening ventral to cephalic protuberance ; oval, about $2 \mu \mathrm{m}$ in diameter. Caudal extremity with four small processes. Oesophagus sinuous, with lumen widening at level of nerve ring then again narrowing ; apparently joining intestine near level of circumoesophageal ganglia. Intestine extending posteriad to near caudal end, opening externally through minute anal pore about $60 \mu \mathrm{m}$ anterior to caudal extremity. Anlage of genital organs bilobed, situated in posterior half of body. Osmocyte large, located about one-third of length of body from cephalic extremity; equal to about one-half diameter of body. Phasmids prominent, with large nuclei; situated bilaterally, and opening through pores on lateral surfaces just posterior to level of anus.

Type host: Big brown bat, Eptesicus fuscus (P. de Beauvois).

Type locality: W. L. Findley National Wildlife Refuge, $17.6 \mathrm{~km}$ south of Corvallis, Benton County, Oregon.

Habitat : Digits of rear feet, in subcutaneous tissues of plantar surface.

Holotype: From big brown bat, collected by C. Maser on 3 June 1974; United States National Museum Helminthological Collection No. 77325. Paratype : From another big brown bat, collected by C. Maser at the type locality on the same date, No. 77326. Two specimens (paratypes) also have been deposited in the collection of the Laboratoire des Vers, Muséum National d'Histoire Naturelle, Nos. $648 \mathrm{NE}$ and 649 NE.

Localization of Nematodes and Tissue-Response of the Host.

In all cases, the nematodes were found in subcutaneous lesions of the plantar surfaces of the digits. In a series of 11 specimens of $M$. lucifugus for which the data 
were recorded, the right foot was affected in one, the left foot in two, and both feet in eight ; in 13 specimens of Eptesicus fuscus, the respective numbers were one, one, and eleven. Infections usually involved one or two digits of a foot, with the nematodes typically localized in tissues of the first or middle phalanx. As shown in Table II, the prevalence of the nematodes was much higher in female bats than in males.

TABLE II. - Sex-ratios of bats examined, and prevalence of Maseria vespertilionis by sex of host.

\begin{tabular}{|c|c|c|c|c|c|}
\hline \multirow[t]{2}{*}{ Species } & \multicolumn{3}{|c|}{ Numbers } & \multicolumn{2}{|c|}{ Infected } \\
\hline & Total & Males & Females & Males & Females \\
\hline Myotis lucifugus & 152 & $53(35 \%)$ & $99(65 \%)$ & $1(<2 \%)$ & $11(11 \%)$ \\
\hline M. volans & 99 & $43(43 \%)$ & $56(56 \%)$ & - & $1(<2 \%)$ \\
\hline Eptesicus fuscus & 82 & $45(55 \%)$ & $37(45 \%)$ & $2(4 \%)$ & $16(43 \%)$ \\
\hline Totals & 333 & 141 & 192 & $3(2.1 \%)$ & $28(14.6 \%)$ \\
\hline
\end{tabular}

Macroscopically, the lesions appeared as small swellings, sometimes situated centrally on the digit, but more often lateral to the flexor tendon. They usually produced some thickening and asymmetry of the affected phalanx, and the overlying skin was characteristically paler in color than that of the adjacent tissue. As in the first infected bat observed, the lesions sometimes opened externally by way of a small fistula about $200 \mu \mathrm{m}$ in diameter. This condition, however, was noted in only four additional animals. In such cases, a small amount of exudate could be expressed from the opening, and in one a mature nematode had partially emerged. In single lesions, numbers of nematodes ranged from one to eight. Within a single lesion, the nematodes often differed in state of development.

Nematodes in situ were found to be reflexed or somewhat coiled within a capsule of connective tissue ( $f$ ig. $5 \mathrm{~A}$ ). As seen in sections, they were typically surrounded by a layer of palisaded macrophages as much as $70 \mu \mathrm{m}$ thick, around which was a layer of connective tissue containing numerous leukocytes ( $\mathrm{fig} .5 \mathrm{~B}$ ). The infiltrating cells consisted of histiocytes and numerous eosinophils. Localization of the nematodes near the flexor tendon caused a marked tenosynovitis of chronic nature. Proliferation of the epithelium and thickening of the synovial membrane were characteristic. Leukocytes also were present within the enlarged lumen of the tendon-sheath. In areas of inflammation, the tunica media of arteries was thickened. Frequently, it was observed that some or all of the nematodes in a single lesion had died and were undergoing degeneration ( $\mathrm{fig} .5 \mathrm{C}$ ). In one case, remains of a nematode were present between the bone of the phalanx and the tendon, suggesting that the tendonsheath may sometimes be invaded. In macroscopic appearance, lesions containing dead nematodes did not differ from those described above. 


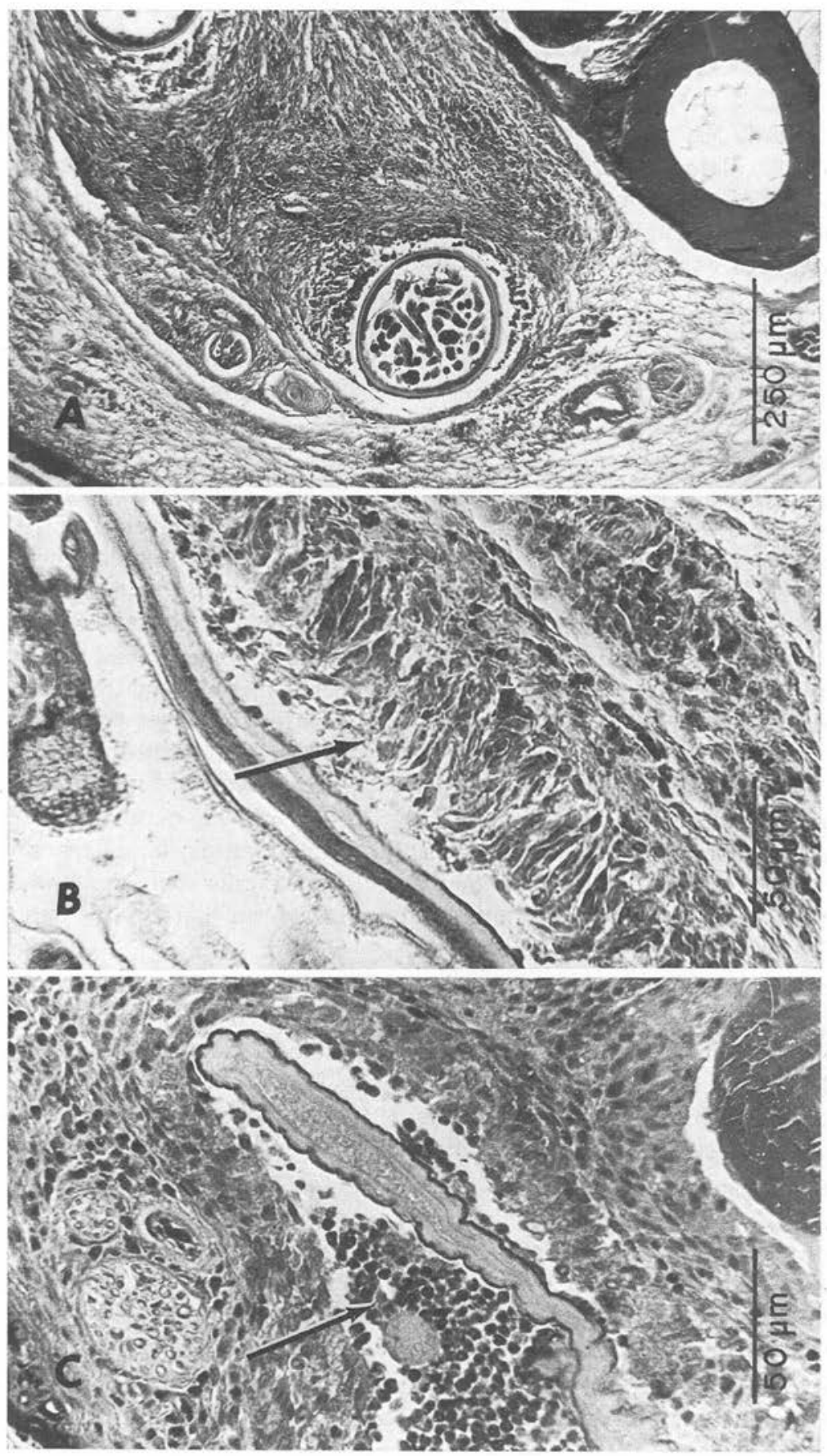

FIG. 5. - Maseria vespertilionis. A-C, nematodes in situ. A) Transverse section of gravid nematodes, lateral to bone of phalanx. Gomori's trichrome. B) Palisaded macrophages (arrow), adjacent to cuticle of nematode. Dark-staining cells are eosinophils. Gomori's trichrome. C) Remains of dead nematode, with aggregation of eosinophils (arrow). Hematoxylin-eosin. 


\section{Discussion}

The family Muspiceidae was established by Brumpt (1930) for Muspicea borreli Sambon, 1925, described from laboratory mice, Mus musculus L. Brumpt recognized (p. 332) that $M$. borreli resembled nematodes in the families Rhabdiasidae Railliet, 1915 and Mermithidae Braun, 1883 in some characteristics, but considered that the discovery of other species of Muspiceids would be required to determine the systematic status of the family. The superfamily Muspiceoidea was established in the order Enoplida by Roman (in Grassé, 1965) to include the monotypic families Muspiceidae, Robertdollfusidae Chabaud and Campana, 1950, and Phlyctainophoridae Roman, 1965. Roman noted that these nematodes had characteristics in common with members of the superfamily Mermithoidea Wülker, 1924, and suggested the possibility of a common precursor.

A fourth genus in the Muspiceoidea, Riouxgolvania, was erected by Bain and Chabaud (1968) for a nematode from the wing-membrane of a bat. The characteristics of this species, $R$. rhinolophi Bain and Chabaud, 1968, provided further indications of affinities between the superfamilies Muspiceoidea and Mermithoidea. In his systematic arrangement of nematodes of the subclass Adenophorea in vertebrates, Chabaud (1974) grouped the superfamilies Dioctophymatoidea, Trichuroidea, and Muspiceoidea in the order Enoplida. Another genus of nematodes from bats, Lukonema Chabaud and Bain, 1974, was placed with Muspicea and Riouxgolvania in the family Muspiceidae. Bain and Chabaud (1979) described two additional species of Riouxgolvania and erected another genus, Pennisia, all from bats. They compared nematodes of the three genera with the original material of Muspicea borreli and concluded that all are members of the family Muspiceidae. They concluded further that the family should be allocated to the suborder Dorylaimina, and that the Mermithoidea, Muspiceoidea, and Trichuroidea form a natural group derived from the Dorylaimoidea.

In the most recent systematic revision of the members of the subclass Adenophorea in vertebrates, Ryzhikov and Sonin (1981) placed the superfamilies Trichocephaloidea (Baird, 1853), Cystoopsoidea (Skriabin, 1923), and Muspiceoidea in the order Trichocephalida Skriabin and Schultz, 1928. They removed the families Dioctophymidae (Castellani and Chalmers, 1910) and Sobolophymidae Petrov, 1930 to the order Dioctophymida Railliet, 1916.

Recently, another muspiceoid nematode, Durikainema macropi Spratt and Speare, 1982, has been described from the mesenteric and portal veins of Macropus spp. (Marsupialia) in Australia. Spratt and Speare (1982) placed the genus in the family Robertdollfusidae. Findings in recent years suggest that muspiceoid nematodes may be well represented in vertebrate hosts, but because of their small size and rather obscure biotopes, may often be overlooked.

The complex of structures which we consider to represent a Demanian system in Maseria vespertilionis has not been observed in nematodes other than certain 
species of the family Oncholaimidae (Enoplida). In addition to the components of the Demanian system, we observed in $M$. vespertilionis distinctive cells which we identified as pseudocoelomocytes. These differed markedly from the multicellular rosettes [designated "uvettes" by Cobb (1930) and others] of the Demanian system. The presence of this system in $M$. vespertilionis would seem to have important implications for the relationships of nematodes of the two suborders involved. Thus far, a Demanian system has been reported in female nematodes representing 11 genera of the family Oncholaimidae : Oncholaimus Dujardin, 1845; Viscosia de Man, 1890 ; Oncholaimellus de Man, 1890 ; Metoncholaimus Filip'ev, 1918 ; Adoncholaimus Filip'ev, 1918; Oncholaimium Cobb, 1930; Metaparoncholaimus de Coninck and Schuurmans Stekhoven, 1933 ; Metoncholaimoides Inglis, 1966 ; Meyersia Hopper, 1967; and Kreisoncholaimus Rachor, 1969 (Schneider, 1939; de Coninck, 1965; Rachor, 1969). Cobb (1930) also reported the presence of apparently homologous tubular organs connecting with the male gonad near the beginning of the vas deferens in oncholaimids of some species.

According to published descriptions (zur Strassen, 1894; Cobb, 1930; and others), the Demanian system (designated "röhrenförmiges Organ" by zur Strassen) is quite variable in form, even in closely related species. Zur Strassen remarked (1894, p. 472) that "In der That ist die Differenz derartig, dass sie zur Bildung besonderer Genera oder selbst Familien Veranlassung geben müsste, wenn sie in gleich hohem Grade bei irgend einem Organsysteme aufgetreten wäre." More recently, Rachor (1969) has discussed the intergeneric and intrageneric differences in the Demanian system in oncholaimids, and has confirmed that it may be either well developed or absent in nematodes of a single genus (e.g., Oncholaimus).

The Demanian system in Maseria vespertilionis, as described above, is fundamentally like that in oncholaimid nematodes, but more complex (fig. 3). The entire system could be traced only in immature females, before the uterus filled with eggs or developing larvae. Later, the system was almost entirely obscured, and the relationships of its components usually were disrupted as the uterus became distended. Only the anteriormost rosette was sometimes visible in gravid specimens. Anteriorly, besides the large osmosium, there was an associated rosette, situated dorsolaterally on the trophosome just posterior to the end of the oesophagus, which received a duct extending anteromediad from the subcuticular tissues ( fig. $3 \mathrm{~A}$ ). This duct was connected with a longitudinal canal in the subcuticular tissues. At this level, two connections with the trophosome were present, each involving a small osmosium associated with the respective rosette. From the anteriormost rosette, the main duct of the Demanian system could be traced posteriad, passing successively through rosettes associated with connections with the trophosome or uterus. Near the caudal extremity, at the level of the posterior ovary, the terminal portion of the duct extended ventrad, and opened by way of a single small papilla on the ventral surface (slightly dextral) of the body. The terminal portion of the duct was surrounded by a rather thick layer of cells, perhaps corresponding to the moniliform gland as described in oncholaimids. The possibility of the existence of additional ventral openings of the system is not excluded. 
Differing opinions have been expressed concerning the function of the Demanian system in oncholaimids. Zur Strassen (1894) considered that components extracted from intestinal content by means of the anterior "rhizopodenartigen Zellen" became mixed with products of the rosettes and the resulting fluid was expelled from the body. He concluded, however, that the secretion had some definite function relating to reproduction. Cobb (1930) suggested that the nearly colorless, sticky secretion produced might in some way protect the eggs after deposition. De Coninck (1965) also considered the adhesive fluid to have a role in reproduction. Rachor (1969) reviewed the features of the Demanian system, and concluded that they supported the concept of a specialized seminal receptacle, in which the spermatozoa were nourished in the secreted fluids, of which the excess was expelled through the terminal pore.

The earlier interpretations do not appear to be applicable to $M$. vespertilionis, although the observations of zur Strassen (1894) may have some relevance. In $M$. vespertilionis, in which the elongated uterine tubes serve as a seminal receptacle in young, proterandric individuals, the Demanian system is connected with both the trophosome and the female reproductive organs. So far as we can determine from the examination of mature nematodes in which eggs were being produced, material from the trophosome and from the rosettes of the Demanian system were mixed in a large sinus situated both anteriorly and posteriorly on the wall of the constricted areas between the ovary and the uterus, through which the oviduct passes (fig. 4). This interpretation of the relationships of the respective structures is supported by the observation that the character of the content of the trophosome adjacent to the connection with the Demanian system differed (i.e., had smaller droplets of lighter color) from that elsewhere in the organ, and by the presence of such small droplets within ducts connected with rosettes. We therefore consider that, in $M$. vespertilionis, the material from the trophosome combined with the secretion of the Demanian system contributes in some way to development of the eggs as they pass through the oviduct. As in the oncholaimids, some of the secretion from the Demanian system is evidently expelled from the body by way of the ventral pore, as indicated by the frequent finding of material extruding from it.

Three larval stages were morphologically distinguishable in gravid specimens of $M$. vespertilionis. The second-stage larvae were typically ensheathed. In contrast to ensheathed larvae of Durikainema macropi, as described by Spratt and Speare (1982), the sheath was not attached at the cephalic end in larvae of $M$. vespertilionis. A prominent feature of third-stage larvae of the latter was a large cell situated about one-third of the length of the body from the cephalic end. Based on the description by Rubtsov (1966) of a similar structure in mermithids, this cell was identified as an osmocyte. Details of its relationships were not established. In gravid females, the pseudocoelom was almost entirely occupied by the uterus distended with larvae. We did not establish the means by which the larvae are expelled. The presence of an apparent pore in the wall of the upper vagina or in the adjacent wall of the uterus suggested a mechanism by which the larvae might enter the pseudocoelom, but none was observed there in the numerous gravid nematodes examined. One female 
that had died within the lesion no longer contained larvae, but no perforation of the cuticle could be discerned except for a ventral opening through which the vulva had extruded. Possibly, the expulsion of the larvae occurs with the death of the gravid female.

The infective larvae of $M$. vespertilionis presumably leave the host by way of a fistula from the subcuticular lesion, described above, after which they probably are free-living until they invade the feet of another bat. Bain and Chabaud (1979) deduced for Lukonema lukoschusi and Riouxgolvania spp. that the larvae directly invade the host-tissue. The larvae of $M$. vespertilionis probably penetrate the rear feet of bats directly at the point of their attachment to surfaces. Disproportionately high rates of infection in female bats (Table II) appear to be related in some way to the formation of maternity colonies, in which adult males usually are not present. This apparent relationship is exemplified by findings in a series of bats obtained by C. Maser from a maternity colony situated in a building : Of 31 females and 3 males of Myotis lucifugus collected, 8 females were infected by $M$. vespertilionis ; of 13 females of Eptesicus fuscus, captured in the same building on the same day, 7 were infected. These data suggest that the aggregation of bats of susceptible species favors transmission of $M$. vespertilionis, but the specific factors involved remain to be defined.

Acknowledgements. This study was based mainly on materials and data very kindly contributed by Mr. C. Maser, Forestry Science Laboratory, Pacific Northwest Forest and Range Experiment Station, Corvallis, Oregon. Bats were collected also in Oregon by Ms. L. Keller, Range and Wildlife Habitat Laboratory, La Grande. Numerous specimens of bats were provided by Mr. D. G. Ritter, Diagnostic Virology and Rabies Unit, Alaska Department of Health, Fairbanks. Dr. A.-G. Chabaud and Dr. O. Bain, Laboratoire des Vers, Muséum National d'Histoire Naturelle, Paris, very kindly provided helpful comments concerning the manuscript (but we alone are responsible for the taxonomic conclusions). At the University of Washington, tissue-sections were prepared by Ms. A. B. Erickson and Ms. L. C. Gibbs. Dr. W. E. Giddens, Jr., reviewed findings in sections. We express our sincere thanks for these contributions.

\section{BIBLIOGRAPHY}

Bann O., Chabaud A.-G. : Description de Riouxgolvania rhinolophi n. g., n. sp., Nématode parasite de Rhinolophe, montrant les affinités entre Muspiceoidea et Mermithoidea. Ann. Parasitol. Hum. Comp., 1968, 43, 45-50.

Bain O., Chabaud A.-G.: Sur les Muspiceidae (Nematoda-Dorylaimina). Ann. Parasitol. Hum. Comp., 1979, $54,207-225$.

Brumpt E. : Muspicea borreli Sambon 1925 et cancers des souris. Ann. Parasitol. Hum. Comp., $1930,8,309-343$.

Chabaud A.-G. Keys to Subclasses, Orders, and Superfamilies. CIH Keys to the Nematode Parasites of Vertebrates, No. I. R. C. Anderson, A.-G. Chabaud, S. Willmott (Eds). Commonwealth Agricultural Bureaux, Farnham Royal, Bucks. I974.

Chabaud A.-G., Bain O. : Données nouvelles sur la biologie des Nématodes Muspicéides, fournies par l'étude d'un parasite de Chiroptères : Lukonema lukoschusi n. gen., n. sp. A nn. Parasitol. Hum. Comp., $1974,48,818-834$. 
Совв N. A. : The demanian vessels in nemas of the genus Oncholaimus; with notes on four new Oncholaims. J. Wash. Acad. Sci., 1930, 20, 225-241.

De Coninck L. : Systématique des Nématodes. pp. 586-68 I, in Grassé P. P., Traité de Zoologie, IV, fasc. 2, Némathelminthes, 731 p. Masson, Paris, 1965.

Rachor E. : Das de Mansche Organ der Oncholaimidae, eine genito-intestinale Verbindung bei Nematoden. Z. Morph. Tiere, 1969, 66, 87-166.

Roman E. : Super-famille des Muspicéides (Muspiceoidea). pp. 721-726, in Grassé P. P., Traité de Zoologie, IV, fasc. 2, Némathelminthes, 73I p. Masson, Paris, 1965.

RubTsov I. A. : K ontogenezu mermisov - parasitov krovososushchikh moshek. Trudy Gel'mint. $L a b .$, I $966,17, \mathrm{I} 28-\mathrm{I} 56$.

RYzhIKov K. M., Sonin M. D. : Sistema nematod - parazitov pozvonochnykh zhivotnykh. Parazitologiia, 1981, Is, 510-518.

SchneIDeR W. : Die Tierwelt Deutschlands und der angrenzenden Meeresteile. Teil 36, Würmer oder Vermes, II : Fadenwürmer oder Nematoden. I : Freilebende und pflanzenparasitische Nematoden. 260 p. Gustav Fischer, Jena, I939.

Spratt D. M., Speare R. : Durikainema macropi gen. et sp. nov. (Muspiceoidea : Robertdollfusidae), a remarkable nematode from Macropodidae (Marsupialia). Ann. Parasitol. Hum. Comp., 1982, 57, 53-62.

Zur Strassen O. : Uber das röhrenförmige Organ von Oncholaimus. Z. wiss. Zool., i 894, 58, 460$474+4 \mathrm{pl}$. 